\title{
An Investigation on Kumiss Treatment in the Context of Health Tourism: A Literature Review
}

\author{
Barış Erdem ${ }^{A}$, İbrahim Gündoğdu \\ Received: May 2018 | Accepted: September 2018 \\ DOI: 10.5937/turizam22-18972
}

\begin{abstract}
Continuing growth and expansion of international tourism around the world has increased competition between countries, which desire to expand shares in the industry. Therefore, many countries are trying to use efficiently their touristic potential, while displaying their efforts. The result of increasing tourism demand is formation of new destinations, which emerge in new market areas. One of these new markets is health tourism. Nowadays health tourism is attracting more attention as a rapidly growing alternative market. As a fact, health tourism is a market worth approximately 100 billion dollars today. Medical tourism travel become especially popular tourism activity and revenue from medical tourism made this field more attractive. Tourists traveling for medical purpose spend their time on recreation, sport and other activities during these tours, however, the main purpose of medical tourism not only getting treatment but also travelling. Kumiss, which is composed from fermented mare milk, has been used in central Asian for medical purposes for centuries and this type of treatment is known to have many benefits. This descriptive study focuses on medical treatment within health tourism. In this context; the definition, content, historical development and benefits of kumiss treatment are emphasized. Besides, information has been given about countries which use kumiss treatment in the world. The findings of the study are expected to bring a new perspective to the health tourism literature.
\end{abstract}

Key words: health tourism, medical tourism, kumiss treatment.

\section{Introduction}

At the present time, international tourism movements continue to grow rapidly. It is undoubtedly considered that for this rapid growth; increase in people's levels of income, based on the rise in their welfare levels, increase in spare times in general, people's intent to discover different places as a result of rapid technological development and easier access to information; have

A University of Balıkesir, Faculty of Tourism, Department of Recreation Management, Çağış Campus, Bigadiç on the way 17. km, 10145, Balıkesir, Turkey \& University of Kyrgyz-Turkish Manas, The School of Tourism and Hotel Management, Department of Tourism and Hotel Management, 56 Chyngyz Aitmatov Avenue, Bishkek, Kyrgyzstan; Corresponding author: berdem2110@gmail.com

B University of Kyrgyz-Turkish Manas, The School of Tourism and Hotel Management, Department of Tourism and Hotel Management, 56 Chyngyz Aitmatov Avenue, Bishkek, Kyrgyzstan 
important roles. International tourism movements have become an important driving force, particularly in economical development of developing countries with their foreign exchange earning aspect. If we also consider the contributions of tourism to inter cultural approaches and thus to universal peace (Yirik, 2014), it sounds normal for it to be accepted as one of the most important industries of today.

In the report published by the World Tourism Organization (UNWTO) in 2017, it is stated that the number of international tourist arrivals reached 1 billion 322 million in the year 2017 . In the predictions for the year 2018, the increase in international tourist arrivals are estimated to rise at a rate of 4-5\%. The European continent still continues to have the biggest share from international tourist arrivals. In the year 2017, the Europe grew at a rate of $8 \%$ compared to previous year and became the region which made the biggest leap in international tourist arrivals together with Africa. The rates of growth were 6\% in Asia and Pacific region, $5 \%$ in the Middle East and 3\% in America (UNWTO World Tourism Barometer, 2018). Considering that the world population is 7 billion and 610 million, it is likely to say that about $18 \%$ of the world population are participating to international tourism movement (http://www.worldometers. info/world-population/). Again according to data from UNWTO, international tourism revenues reached 1 trillion and 220 billion dollars in the year 2016. Distribution of revenues created by international tourism movements according to continents are as; Europe (36,7\%), Asia and Pacific (30,1\%), America (25,7\%), the Middle East (4,7\%) and Africa (2,9\%). Besides, when we take a look at travel intentions of the people participating to international tourism movements, it appears as the visits for spare time, entertainment and holiday purposes (53\%), for friend and relatives, health, religion and other purposes (27\%), for business purposes (13\%) (UNWTO Tourism Highlights, 2017)

Besides, it is witnessed that a fierce competition is experienced in our day between the countries to get more share from international tourism movements. In this context, many countries are in an effort to effectively use the tourism potential that they possess. One of those efforts are for diversifying the tourism and spreading it in a whole year. In this context, it is observed that new alternatives have started to emerge in our country nowadays in addition to sea-sun-sand triangle sense of holiday. One of those is the health tourism.

Health tourism can be defined in its simplest form as "the voyage made from the place of residence to another place (domestic or international) in order to have a service due to any health reason" (Turkish Association of Health Tourism, 2018). According to Turkish Republic Ministry of Culture and Tourism definition, health tourism are the journeys which are made for treatment purposes. It is stated that health tourism is a type of tourism which allows growth of health institutions by using international patient potential together with the ones who need physical therapy and rehabilitation (Turkish Republic of Ministry of Culture and Tourism, 2018a). In the literature, some of the definitions made related to health tourism can be listed as follows:

According to Kördeve (2016), health tourism is "traveling of people from their place of residence to another place in order to protect their health, and have physical care, diet, healthy nutrition, relaxation and mental training in a hotel having professional knowledge".

Goodrich and Goodrich (1987, cited by Temizkan et al., 2015: 396) defined health tourism as "the effort to increase touristic attractiveness of a touristic facility or a region through developing its current resources, health services and facilities".

Zengingönül et al. (2012) state that the ones who want to benefit from health tourism act not only considering the doctors or prices in their countries to solve their health problems, but also the best solution and best price options. Based on that, the authors defined health tour- 
ism as "all the activities arising from intercity or transnational travels with treatment or holiday purposes".

From the past to present, people have been in search of different solutions at times they lose their health. As a result of these searching, various travels took place continuously from the place of residence to other places in order to have treatment. In the health tourism report of Association of Turkish Travel Agencies (TÜRSAB), health tourism was stated as a type of tourism which has been known since Ancient Greece. It is known that the Greek patients poured in the town of Epidauria for treatment at those times. And the name of this town is referred as the place where the god of medicine Asklepios used to live. During the following centuries, patients who were seeking recovery have traveled to places where Salus Per Aquam (SPA) meaning health with water or senatoriums (health centers) were present (Türsab Health Tourism Report, 2013). In other sources, it is stated that the historical past of health tourism is based on antique civilizations. Among those civilizations, it is stated that Sumerians built the oldest health facilities around hot resources and that those facilities were very big temples that contain water flowing pools (The Health Foundation of Turkey, 2010). On the other side, not only rebirth of art and culture took place in Europe and England with Renaissance, but also health tourism showed up. For example, Ville d'Eaux (Water Town) which was founded in the year 1326, has become famous in a short time in Europe as it had iron rich hot water resources, and people such as Peter the Great and Victor Hugo visited this place. Also in the 16th century, touristic towns with SPAs were discovered by Europeans such as St. Mortiz, Ville d' Eaux, Baden Baden, Aechen and Bath in England. For example, with the development of health tourism; roads were paved, streets were lightened, hotels and restaurants were improved in Bath town (Zengingönül et al., 2012).

In our day, a number of reasons such as health cost increases in various countries has featured the countries which are able to do this business economically and with a better quality, and this situation allowed the formation of health tourism sector in world tourism. In this context, it is mentioned that the number of patients participating to health tourism as of the year 2012 reached 50 million and that the health tourism has a market volume of approximately 100 billion dollars. In addition to that, it is asserted that the market volume of health tourism is growing in the world with an increase rate of $20-30 \%$ annually (Western Mediterranean Development Agency, 2013; Erdem et al., 2015a; Aydın, Aydın, 2015).

In the literature, it is stated that the health tourism is generally split into three types. These are (The Health Foundation of Turkey, 2010; Zengingönül et al., 2012; Türsab Health Tourism Report, 2013; Daşdan, 2014; Erdem et al., 2015a; Turkish Republic of Ministry of Culture and Tourism, 2018a) medical tourism, thermal tourism and elderly and disabled tourism. In this study, medical tourism is focused on.

According to Erdem et al. (2015a), medical tourism comprises the visits for treatment purposes which include utilization of some health services by individuals carried out at hospital environments. The authors showed plastic surgery operations, eye impairment correction operation, tooth treatments, cardiac operations and test-tube baby practices as samples for these treatment services. Kördeve (2016) described medical tourism as the journeys which are made usually from high income countries to middle or low income countries in order to get cheaper health service. Such journeys may be between cities in the same country or be an international travel. In this context, the author states that medical treatment services should come to mind when medical tourism is mentioned.

Beladi et al. (2017) defined medical tourism as a phenomenon which the people travel abroad in order to access medical treatment. The authors assert that many countries started 
to use medical tourism to revive their economies particularly after the global financial crisis experienced in the year 2008. Moreover, it is stated that many countries in Asia placed importance to present and develop their medical tourism industries as of the Asian financial crisis in the year 1997 .

In the present time, the destinations which the people mostly travel for medical tourism purpose include countries such as Turkey, India, Malaysia, Brazil, Thailand, Mexico, Costa Rica and Singapore (Stephano, 2018). For example, India is considered among the important actors in medical tourism sector. The biggest superiority of India in this field stands out in price-quality balance. In other words, India is able to offer a quality health treatment for much cheaper prices than the ones in United States of America (USA). From this aspect, India is characterized as one of the most important destinations in field of health tourism. Likewise, Malaysia can also offer a quality service in medical tourism for much cheaper prices compared to USA. It is stated that hospital rooms in Malaysia have the comfort just in like five star hotels. Moreover, tourists who come to Malaysia for health tourism meet with this comfort even at the airport. Within this scope, Malaysia Health Travel Council) (MHTC) provides lounge and concierge services at Kuala Lumpur and Penang airports. Consequently, Malaysia succeeded in receiving the best health and medical tourism award from International Medical Travel Journal (IMTJ) in the year 2015. With its worldwide known plastic surgeons, Brazil was also determined by the World as the country that offers the best health service. Patients coming to Brazil mostly receive cosmetics and plastic surgery services. (Stephano, 2018). Besides, Thailand is accepted as an important destination in terms of medical tourism. The country features with aesthetics surgery in medical tourism (İçöz, 2009). It is stated that Thailand hosts approximately 1.5 million tourists annually for only health tourism purpose (Daşdan, 2014).

Besides, although there is not much available in the relevant Turkish literature, it is known that the drink kumiss produced from mare's milk has been used for treatment purposes particularly in the Central Asia for years. Although kumiss treatment has an important health potential particularly in Central Asia countries, a significant lack of presentation in this field leads to failing to utilize that potential sufficiently. In this descriptive study; conceptual content and historical development of kumiss phenomenon as well as the benefits of kumiss treatment and current practices for kumiss treatment in some countries in the world were emphasized. The findings revealed in the study are expected to bring a new point of view to the health tourism literature.

\section{Conceptual Content of Kumiss Phenomenon and Kumiss Treatment}

The word kumiss is widely used by many societies in Ural-Altaic language group which the Turkish language is included in. It is pronounced as koumiss, kumiss, kuymiss, kymyz, qymyz, qımıź, kumiz in various countries (Tegin, Gönülalan, 2014). Kumiss is a yeasty, dairy and alcoholic beverage which is produced from mare's milk and consumed by Turks in the Central Asia with pleasure. Kumiss is in white colour and more fluid and pure compared to milk. It is a beverage which does not contain curd particles in it. It has a unique taste, odour and aroma. No foreign odour is available in kumiss other than alcohol odour. However, alcohol rate in kumiss is quite low. This rate is close to the rate of alcohol included in many fruits i.e. orange, tangerine etc. It is stated that the people who drink kumiss for the first time tell that they feel a harsh (somewhat astringent) taste, but used to this taste as they continue drinking (Karagözlü, 2003). 
It is believed that the first horses have been domesticated around 2500 B.C. Outram, one of the professors of Exeter University in England; found a large number of horse teeth during his excavations at Botai archaeological site of Kazakhstan in the year 2009. Outram determined that the horse teeth were from 3500 B.C., and stated that they belonged not to wild horses but to domesticated ones. This discovery has proven that the oldest horse domestication took place in Kazakhstan. Outram stated that the horse remains he found were much more than the human remains. And this observation was expressed to have shown that Botai civilization was the oldest society that raised horses. Accordingly, it was concluded that Botai people started to raise horses 5500 years ago, and that the horses were used for traveling on instead of plowing. In some of the bowls found at Botai cemeteries, fat remains of horse milk was proven to exist. Upon the finding of kumiss mixers and bowls buried together with the dead in cemeteries, the oldest kumiss was declared to have been made 5500 years ago (Akbulut, 2015).

The first scientific knowledge about the chemcal structure of kumiss was the report written by the Scotchman Griw in 1784, who was in charge of the Russian army. But before this report, the Frenchman W. Rubrikas who traveled to the region where Tatar Turks were living in the year 1253; gave information about how kumiss was made, its taste, intoxicant property as well as its effects on human health. Before these information, Heredotos also stated when mentioning Scythians that they obtained spirit from mare's milk. But after Heredotos, no author in the West have mentioned kumiss until the 12th century. After the 12th century, it was seen that kumiss was mentioned in Russian chronicles (Aksoy, 1998).

It is known that kumiss has been used for hundred years in treatment of anemia, emaciation and tuberculosis disease. Kumiss has become worldwide famous during 1800 s as a miracle drug, and kumiss treatment sanatoriums were established in Russia. Again it was asserted that tuberculosis, pneumonia, chronic cough and anemia was treated by kumiss (Aksoy, 1998). It is stated that the reason for many diseases is the disorders in gut flora. Particularly with the development of undesired microorganisms in gut flora, toxic materials are formed and intestinal mucosa gets damaged. Thus some diseases occur as a result of that. Kumiss is produced from neuraminic acid rich mare's milk and when it is taken into the body, bifidobacteria and lactic acid bacteriacontrol the gut flora and reduce $\mathrm{pH}$ (Power of Hydrogen). Thus, the development of pathogenic microorganisms which were grown in the alkali environment after $\mathrm{pH}$ decrease is prevented (Yilma, Kurdal, 2002).

In the study of Berlin (1962, cited by Kirdar, 2017) which includes physical and chemical properties of mare's milk and kumiss plus production technology and therapeutic features; he mentioned that type of kumiss might also change according to yeasting time during its preparation stage. In this context, the author stated that the kumiss made from mare's milk was split into three groups as weak, moderate and hard, properties of which are given as follows:

- Weak kumiss: Fat 1\%, titration acidity 24-32 SH (Soxhlet Henkel acidity), alcohol 1,0\%;

- Moderate kumiss: Fat 1\%, titration acidity 32,4-40 SH, alcohol 1,5\%;

- Hard kumiss: Fat 1\%, titration acidity 40,4-48 SH, alcohol 3,0\%.

Accordingly, it is likely to say that kumiss treatment varies according to type of the disease. While weak kumiss is used in some diseases, hard kumiss can be used for some other diseases. Even for digestive system diseases, fresh mare's milk is used. Treatment methods are applied by specialists according to disease of the patient (Kırdar, 2017).

Mare's milk has similar properties with breast milk structure. It contains a lot of minerals and vitamins inside. Since majority of the proteins within its structure are decomposed through microbiological activities, it is easy to digest. Due to its low rate alcohol, it positively 
affects the nerve system to some extent. Kumiss is appetizing, it increases digestive juice secretion and speeds up gastric and bowel movements. Moreover, it increases the body's capacity to utilize other nutrients (Karagözlü, 2003).

It was revealed by many researchers that kumiss gives positive results in treatment of nerve and digestive system, respiratory tracts and diseases such as tuberculosis, dysentery, typhoid, paratyphoid, ulcer and hepatitis (Kirdar, 2017). Yaygın (1991) states that it is determined by scientific studies that kumiss is the most effective drug particularly in treatment of pulmonary tuberculosis and that patients with tuberculosis in many sanatoriums of Russia are healed rapidly by kumiss. The author also points out that kumiss is a valuable, thirst-quenching food that increases the desire to work, and with this aspect; that it should be recommended not only to patients but to everyone whether young or old.

\section{Some Examples of Kumiss Treatment Practices Around the World}

The countries where the most common kumiss treatment is used are Kyrgyzstan, Kazakhstan, Tatarstan and Russia. It is witnessed that the kumiss treatment centers in these countries increase their activities particularly during the spring months. Patients coming from different countries and have liver and stomach disorders are located at motels nearby small horse farms on tablelands. Here, they receive kumiss treatment for one week by drinking the horse milk received four times a day (Kaya, 2016).

Kumiss treatment is also seen in Turkey even a little. The most well-known place in Turkey for kumiss treatment is the Kumiss Farm in Kemalpaşa which has been in service for 31 years. The owner of the farm says that he bought this valley resembling Altai Mountains in the year 1987 for the purpose to establish Otağ (Tents) meaning "Land" of all Turkic tribes, and for his ancestors' drink kumiss. The farm owner first focused on the internal pattern. For that purpose, he invited the famous Kazakh parinter Aman Abzalbek to the farm and built an Otağ drawn by him. The Otă̆ has a unique seating arrangement. The people who know the customs of Ota $\breve{g}$ sit on the places they are required to when they get in according to their ages and statuses. In addition, because of the Kazakhstan view formed by the youth riding horses with their national clothes on and since the farm's owner is a Kazakh Turk, Turkish media has called that place "Mini Kazakhstan" or "The Kazakh Valley". Alaş kumiss production unit located in Kazakh Valley-Kumiss Farm is the first and only unit in Turkey making kumiss production (http://kimizciftligi.com/basinda-biz; Turkish Republic of Ministry of Culture and Tourism 2018b).

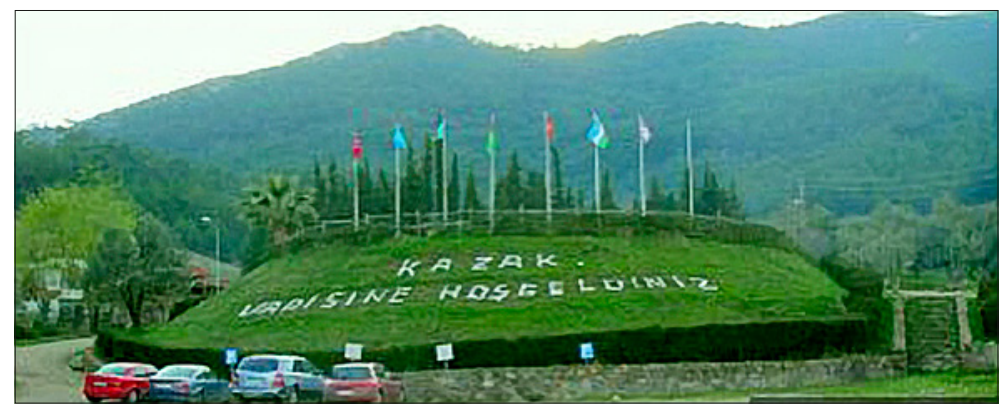

Figure 1. Kemalpaşa Alaş Kazakh Valley Kumiss Farm Source: http://www.izmirkulturturizm.gov.tr/TR,77387/kemalpasa-alas-kazak-vadisi-kimiz-ciftligi.html 


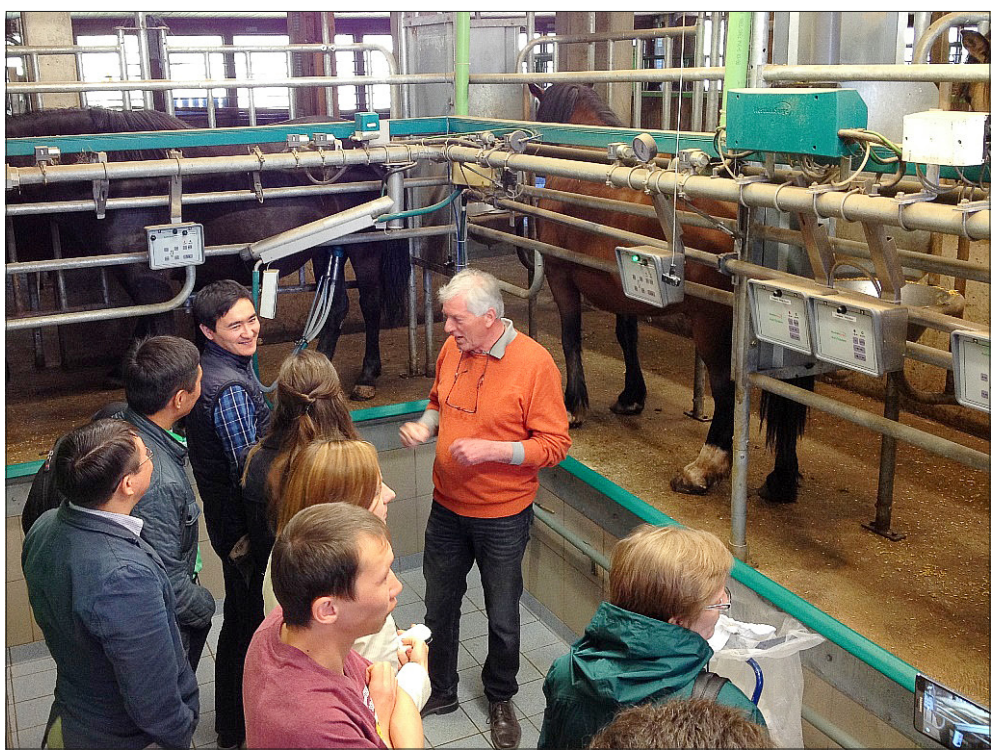

Figure 2. Kumiss Production Facilities in Germany

Source: https://www.managerprogramm.de/wP-content/uploads/2015/07/MP-BWI-KAS-2015-036.jpg

Kumiss treatment examples are also seen in Europe. The German B. Zollman, who was taken captured by the Russians during World War II, caught tuberculosis disease at Karlag labor camp in Russia. When Zollmann was about to die due to tuberculosis when he was released, he stated that he was taken to a village by a Kazakh shepherd and treated by drinking kumiss. Zollmann established a farm with 400 mares in Germany and started to produce kumiss. Besides, another German soldier R. Storch who was taken captive from Russians at World War II, stated that he saw sanatoriums in Russia where diseases like tuberculosis and pneumonia were treated by kumiss. When Storch returned to Germany, he bought mare and established a kumiss sanatorium (Akbulut, 2015).

It is stated that this enterprise in Image 2 has been active in Germany as of the year 1959, and that it is known as a pioneer for farm products and mare's milk products.

Horse milk started to become popular in Germany with World War I. Today, it is consumed as a beverage and a health product in some parts of Western Europe. It is even stated that the horse milk is sold in Germany at horse milk markets as fresh, deep frozen $\left(-18^{\circ} \mathrm{C}\right)$, in powder or fermented forms (Tegin, Gönülalan, 2014).

Besides, trotting horses are shown among the popular races in Belgium for the farmers to use in milk production. Horse milk utilization is so much popular in Belgium that a Horse Milk Dairy Association is stated to exist in Belgium that measures the milk quality of products made from horse milk i.e. yogurt, ice-cream and liqueur (McNivan, 2013). Furthermore, there are websites which sell the cosmetic drugs produced from horse milk in Belgium (http://www. paardenmelk.be). Again in Belgium, there are big facilities producing mare's milk. One of them is the Paardenmelkerij kumiss facility. In this facility, it is possible to accommodate and consume horse milk products (http://www.paardenmelkerij.info/n/en/visits).

In our day, significant progresses were made on mare's milk production as a human food in Western Europe. The interest in horse milk is increasing day by day in Europe as it is believed to be useful in treatment of some allergic and metabolic diseases. It is stated that the demand growth occurred because of this interest leads to increase in mare's milk prices (Tegin, Gönülalan, 2014). 


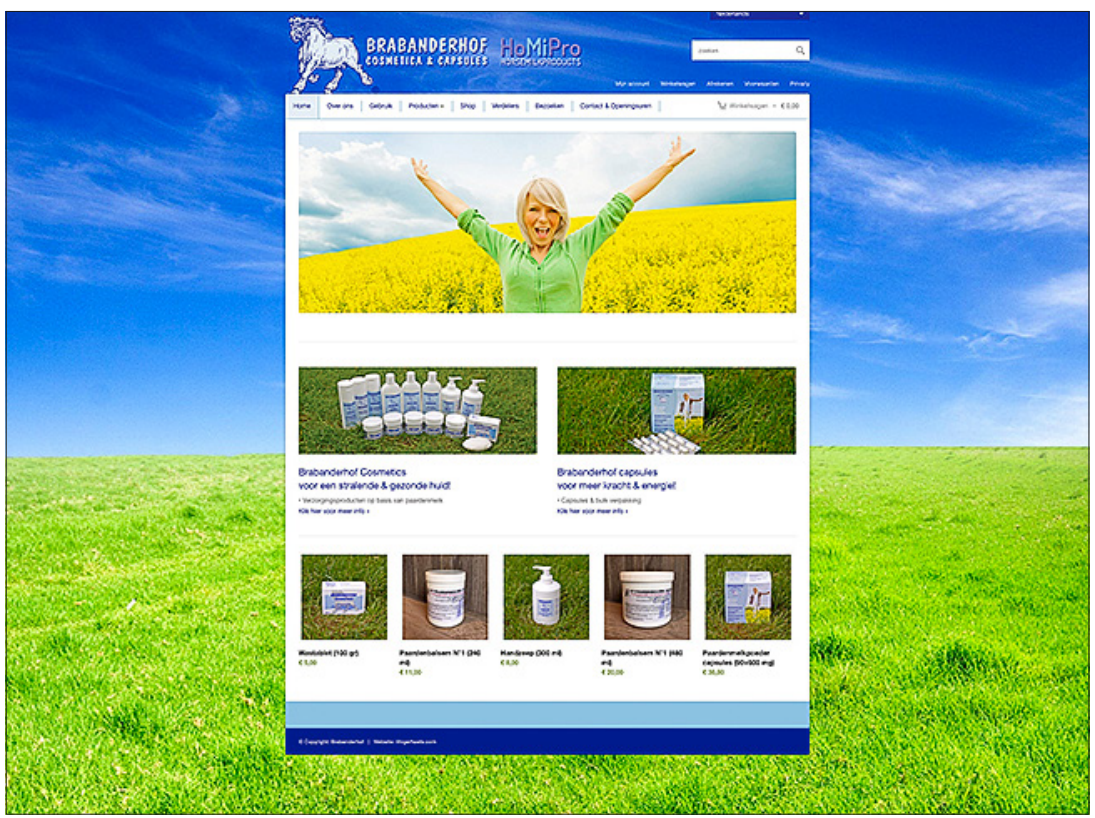

Image 3. A Website Selling Horse Milk Products in Belgium Source: http://www.paardenmelk.be

On the other hand, kumiss treatment is also used commonly in Kyrgyzstan which is considered as one of the countries that have important tourism potential of Central Asia. In this country, kumiss treatment is mostly carried out at sanatoriums and facilities known as kurort as well as at tableland hotels located in rural areas.

Table 1. Tourism Establishments in Kyrgyzstan

\begin{tabular}{|c|c|c|c|c|c|c|c|c|c|c|}
\hline \multirow{2}{*}{ Type of Establishment } & \multicolumn{2}{|c|}{2011} & \multicolumn{2}{|c|}{2012} & \multicolumn{2}{|c|}{2013} & \multicolumn{2}{|c|}{2014} & \multicolumn{2}{|c|}{2015} \\
\hline & Number & $\%$ & Number & $\%$ & Number & $\%$ & Number & $\%$ & Number & $\%$ \\
\hline Hotels & 123 & 4.76 & 132 & 4.9 & 142 & 4.9 & 146 & 4.9 & 157 & 5.0 \\
\hline $\begin{array}{l}\text { Tourism Establishments } \\
\text { and Resting Facilities }\end{array}$ & 185 & 7.17 & 188 & 7.0 & 2002 & 7.0 & 210 & 7.0 & 224 & 7.1 \\
\hline Restaurants & 346 & 13.41 & 357 & 13.3 & 380 & 13.3 & 393 & 13 & 411 & 13 \\
\hline Travel Agencies & 1843 & 71.46 & 1925 & 71.4 & 2049 & 71.5 & 2172 & 72 & 2274 & 72 \\
\hline Sanatorium and Kurort & 72 & 2.79 & 73 & 2.7 & 74 & 2.6 & 75 & 2.5 & 73 & 2.3 \\
\hline $\begin{array}{l}\text { Nature Protection Areas } \\
\text { and National Parks }\end{array}$ & 10 & 0.38 & 19 & 0.7 & 19 & 0.7 & 19 & 0.6 & 19 & 0.6 \\
\hline Total & 2579 & 100 & 2694 & 100 & 2866 & 100 & 3015 & 100 & 3158 & 100 \\
\hline
\end{tabular}

Source: Tourism Data of Kyrgyz Republic National Statistics Committee, 2016, http://stat.kg/en/statistics/turizm/

As seen in Table 1, there are 73 sanatorium and kurort facilities in Kyrgyzstan as of the year 2015. Sanatoriums are the establishments providing therapeutic and preventive medical services. The difference of sanatoriums from other medical establishments is that people can also make holiday in such kind of establishments and that medical services are based on natural resources (https://en.wikipedia.org/wiki/Sanatorium). Kurort is a word of German origin. 
In German language, "Kur" means cure and "Ort" means place. Kurorts are the healing places where patients or people traveling for entertainment purposes visit. The difference of kurort type facilities from other recreation establishments is that natural resources are used for therapeutic purposes and that facilities have the required physical infrastructure in this sense. Thus, medical aid services can be given in kurort facilities for the tourists who seek solution for their various disorders (https://ru.wikipedia.org/wiki/Курорт). In brief, the difference of sanatorium and kurort type establishments arise from their place of establishment. While a facility must be established at a healing area to be defined as kurort, sanatoriums do not have this kind of requirement (Erdem et al., 2015b: 78). In these samatorium and kurort facilities, kumiss treatment is quite common. Kumiss is the national drink of Kyrgyzstan and has been proved in many studies that it is useful for health (Tegin, Gönülalan, 2014; Kırdar, 2017). Morover, it is known that a large number of foreign tourists come to Kyrgyzstan from neighboring countries in order to have kumiss treatment.

In Russian history books, it is written that kumiss is offered to important guests visiting Kyrgyz Khans. Besides, Kyrgyz people also consider kumiss as a heal and use it in some diseases for treatment purposes (Akbulut, 2015).

As seen also in Image 4, kumiss treatment is used almost in every region of Kyrgyzstan. The region where the facilities providing kumiss treatment are located most is the Chuy region which also includes the capital Bishkek. Prices in these facilities are determined according to service given. Nevertheless, it is stated that the daily average prices are between 1200 som (approximately 18 dollars) and 19000 som (approximately 280 dollars). Patients staying in those

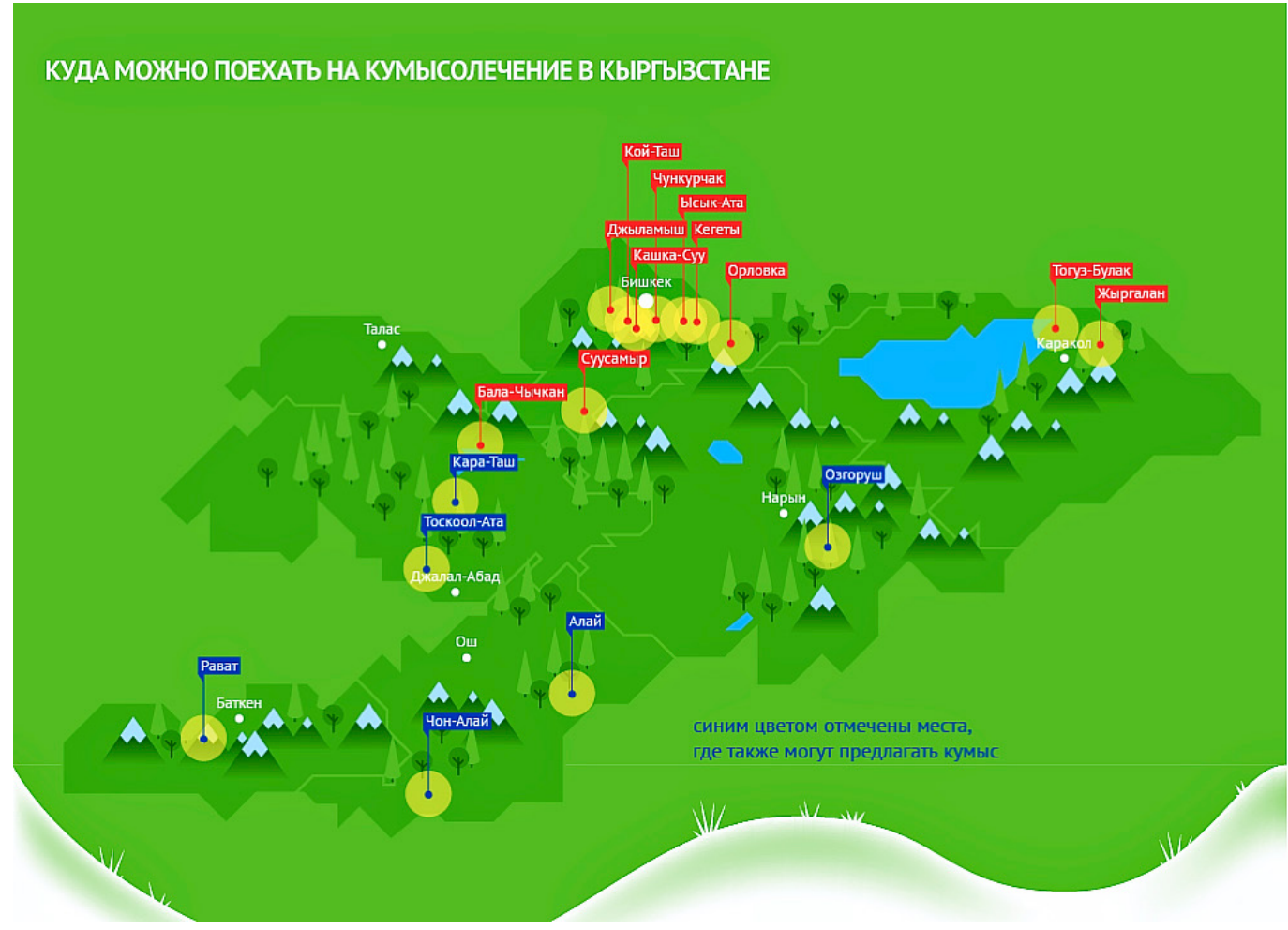

Figure 4. Distribution of Kumiss Treatment Facilities by Region Source: https://ru.sputnik.kg/infographics/20170525/1033394423/kumysolechenie-v-kyrgyzstane.html 
places drink fresh mare's milk five times a day to get treated. (https://ru.sputnik.kg/infographics/20170525/1033394423/kumysolechenie-v-kyrgyzstane.html).

In Kazakhstan, which is another country in the Central Asia; the first kumiss treatment center was opened in the year 1854 in Bogdanovka village of Samara state. The findings in Kazak steppes belonging to 5500 years before reveal that the nomad people who had lived there also used kumiss for treatment purpose. The kumiss technology which has been prepared by nomads for centuries, was kept hidden. It is known that Kazakhs also used kumiss in treatment of tuberculosis during antique ages. In our day, there are many kumiss treatment centers in Kazakhstan. One of these facilities is "Okzhetpes", which is located along Burabay Lake in Shuchinsk Town of Astana. In this facility, patients are applied kumiss treatment under physicians' control (https://www.zakon.kz/4776853-kumys-kak-lekarstvo.html).

Besides, kumiss cure is also applied to tuberculosis patients in some hospitals of Russia in addition to modern drugs. It is also asserted that kumiss increases the effect of modern drugs and reduces their side effects (Akbulut, 2015). Therefore, kumiss treatment is quite common in Russia. Kumiss treatment centers have become widespread in Bashkortostan, Chernebinks Region, Southern Ural, Volga region and Salsk steppe. Yumatova sanatorium in Bashkortostan is an example of those. This kumiss center which was opened in 1934, has succeeded to survive until today (https://sankurtur.ru/methods/1986\#kumys-6).

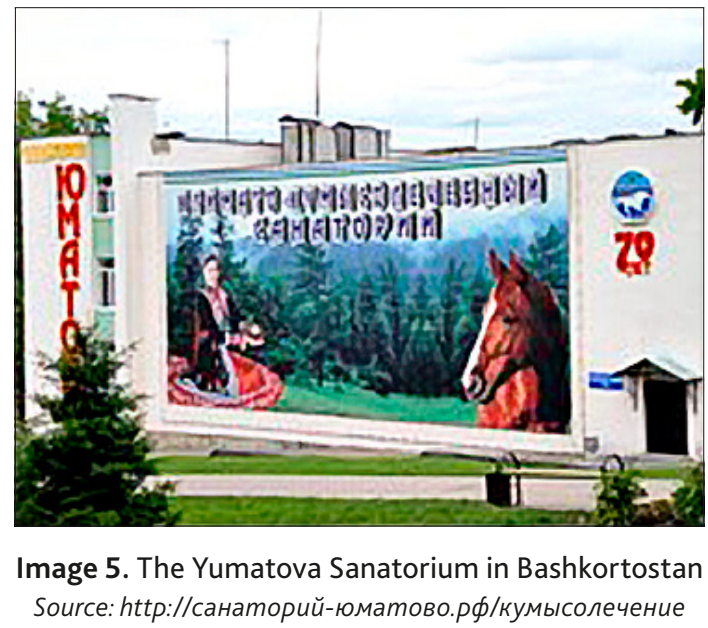

Mongolia is famous with its horse culture and horse products are considered as an important part of the national cuisine in this country. The importance of kumiss in Mongols is described with the phrase 'Each Mongol house becomes a milk industry center in summer months'. In Mongolia, kumiss is widely used in traditional medical practices for treatment of diseases i.e. tuberculosis, anemia, cardiac and vascular diseases, diabetes and gynecological disorders (Park1, 2009).

\section{Conclusion}

As the international tourism movements continue to grow worldwide, it is witnessed that new types of tourism appear based on the diversifying travel tendencies of tourists. One of them is the travels made for medical purposes. In medical tourism, the basic travel motivation of tour- 
ists is to have treatment. The people may travel to overseas countries in order to find solution for their various disorders. The opportunity to get the same or more qualified treatment methods in a cheaper way may lead tourists to international travels for medical purposes.

Although not much included in the relevant tourism literature, kumiss has started to attract the attentions of academicians studying on health tourism in recent years as it has been used for medical purposes particularly in the Central Asia for years. Kumiss is a dairy product made from mare's milk and has been consumed gladly by Nomad and Turkic people for thousand years. From the past to present, kumiss has succeeded to survive with 5500 years of past and become a natural drug and national drink of the said countries.

However, there are serious deficiencies particularly related to definition in utilization of kumiss treatment method for health tourism purpose. In other words, it is remarkable that many tourists who have the potential to request health tourism products are not able to create sufficient demand due to lack of knowledge about kumiss. In this sense, in order to provide international recognition of kumiss which is particularly produced in the Central Asia, there is a need to define it as a geographical sign (Tegin, Gönülalan, 2014).

Besides, there are still many presentation deficiencies about facilities providing health service in the Middle Asia. It is impossible to reach adequate information in matters i.e. in which locations are the relevant facilities located, what kind of health service do they provide, their infrastructure opportunities, physical and human resources. Therefore, there is a need to handle the official web sites of relevant facilities again and to promote such facilities effectively. As the kumiss treatment has been discovered in some European countries recently, the Middle Asia countries are under threat in terms of competition at health tourism market. Even though it is unknown how many international tourists come to the Central Asian countries for kumiss treatment or health purpose in general, it is deemed as an obligation to take strategical decisions for better promotion of kumiss treatment in this country. Other suggestions in this topic can be listed as follows:

- The development of health tourism in Central Asia depends on improvement of infrastructures and superstructures to a certain extent in the countries of that region. It is observed that the facilities offering kumiss treatment in Central Asia are usually concentrated in rural areas, particularly at tablelands. Accordingly, the means of infrastructure required for transportation to such facilities should be completed. Also considering that tourists staying in these facilities do not only receive kumiss treatment, it is important to improve rest and entertainment opportunities in such facilities.

- It is seen that in Central Asia, there are a very limited numbers of travel agencies or tour operators that focus on organizing tours related to health tourism. Especially the tours that travel agencies would organize related to kumiss treatment may help better recognition of this tourism type and consequently increase in tourism demand towards the region.

- Even the benefits of kumiss had been medically proven in many researches, the kumiss phenomenon has not been yet enough recognized within health tourism throughout the world. In order to attract the attentions of academicians who have an interest particularly in health tourism, it would be useful to organize scientific activities on health tourism in Central Asia e.g. symposium, congress.

- On the other side, a particular importance may be attached to health tourism at a level of Ministry of Tourism in Central Asia where kumiss treatment is widely used. In those countries, allocating more resources for health tourism both at a level of Ministry of Tourism and private sector may increase the region's competitive power in tourism. 
In this study, kumiss treatment which is thought to be a new type of medical tourism was focused on, and in this context; examples were tried to be presented from practices of some countries which apply kumiss treatment in the world. As the studies conducted on kumiss treatment under health tourism are quite limited in particular, this reveals that there is a requirement to make more research in this field in the future. In this context, empirical studies to be conducted particularly on kumiss treatment in Central Asia as a type of medical tourism are thought to make important contributions to the relevant literature.

\section{Acknowledgements}

This study has been derived from the master thesis titled "An Investigation on Kumiss Treatment in Kyrgyzstan in the Context of Health Tourism", which was prepared by Ibrahim Gündoğdu under the supervision of Assoc. Prof. Dr. Barış Erdem at Kyrgyz-Turkish Manas University, Institute of Social Sciences, Department of Tourism and Hotel Management.

This study has been presented as a proceeding in the grd International Congress on Entrepreneurship organized by Kyrgyz-Turkish Manas University in Bishkek city of Kyrgyzstan in the date 10 - 12 May 2018.

\section{References}

Akbulut, U. 2015. Kımız: Orta Asya'nın Binlerce Yıllık İçeceği, Retrieved March 10, 2018, from http://www.uralakbulut.com.tr/wp-content/uploads/2015/o3/KIMIZ-ORTA-ASYANINBİNLERCE-YILLIK-İÇECEĞİ-1-MART-2015.pdf (in Turkish).

Aksoy, M. (1998). Türkler'de At Kültürü ve Kımız. Türk Dünyası Tarih Dergisi, Ekim, 38-44. Retrieved May 26, 2018, from http://www.mustafaaksoy.com/dosyalar/Turklerde-At-Kulturu-ve-Kimiz.pdf (in Turkish).

Aydın, G., Aydın, B.K. 2015. Dünyada ve Türkiye'de Sağlık Turizmi Pazarlama Uygulamaları ve Karşılaştırmalı Durum Analizi. Pazarlama ve Pazarlama Araştırmaları Dergisi 16, 1-21 (in Turkish).

Beladi, H., Chaho, C. C., Ee, M.S., Hollas, D. 2017. Does Medical Tourism Promote Economic Growth? A Cross-Country Analysis. Journal of Travel Research oo(o), 1-15. Retrieved March 25, 2018, from http://journals.sagepub.com/doi/pdf/10.1177/o047287517735909

Berlin, P.J. 1962. Kumiss. In Bulletin 4, International Dairy Federation, Brussels, Belgium, 4-10.

Daşdan, İ. 2014. Türkiye'de Sağlık Turizmi: Türkiye ve Özelinde İzmir'de Sağlık Turizminin Mevcut Durum Analizi ve Strateji Önerileri. Mehmet Akif Ersoy Üniversitesi Sosyal Bilimler Enstitüsü Dergisi 6(10), 143-163 (in Turkish).

Erdem, B., Gülcan, B., Chykynov, S. 2015a. Konaklama İşletmelerinde Spa \& Wellness Hizmetlerinde Çalıșan İșgörenlerin Profili: Antalya'daki Beș Yıldızlı Otel İşletmelerinde Bir Araştırma. Akademik Bakış Dergisi (48), 238-257 (in Turkish).

Erdem, B., Gülcan, B., Tokmak, C., Asanova, K., Margazieva, N. 2015b. Kırgızistan Konaklama Sektöründe İnsan Kaynakları Profili Araştırması. Manas Sosyal Araştırmalar Dergisi 4(3), 69-92 (in Turkish).

Goodrich, J.N., Goodrich, G.E. 1987. Health-care Tourism - An Explanatory Study. Tourism Management 8(3), 217-222. 
İçöz, O. 2009. Sağlık Turizmi Kapsamında Medikal (Tıbbi) Turizm ve Türkiye'nin Olanakları. Journal of Yaşar University 4(14), 2257-2269 (in Turkish).

Karagözlü, C. 2003. Kımız Üretim Tekniği, Çiftçi Broşürü:45, Ege Üniversitesi Tarımsal Uygulama ve Araştırma Merkezi, Retrieved March 10, 2018, from https://www.google.com/ url?sa=t\&rct=j\&q=\&esrc=s\&source=web\&cd=1\&ved=oahUKEwiyx7Do7fPZAhVJLZoKHQ9tA9sQFggmMAA\&url=http\%3A\%2F\%2Fwww.agr.ege.edu.tr\%2Ffiles\%2Fdepo\%2Fciftci_ brosur\%2FKimizuretimTeknigi.doc\&usg=AOvVawoAnawchtAG4orYayK_loda (in Turkish).

Kaya, F. 2016. Orta Asya'da Kımız Tedavisi. Insan ve Hayat Aktüel Kültür Dergisi, Retrieved March 10, 2018, from http://insanvehayat.com/orta-asyada-kimiz-tedavisi/ (in Turkish).

Kırdar, S.S. 2017. Kısrak Sütü ve Kımız. Süt Ürünleri Gıda Tarım ve Hayvancılık Dergisi (12), Retrieved March 19, 2018, from https://www.researchgate.net/publication/317357695 (in Turkish).

Kördeve, M.K. 2016. Sağlık Turizmine Genel Bir Bakış ve Türkiye’nin Sağlık Turizmindeki Yeri. Uluslararası Sağllk Yönetimi ve Stratejileri Araştırma Dergisi 2(1), 51-61 (in Turkish).

McNiven, D. 2013. İngersolltimes: Horse Milk an Expensive Delicacy, Retrieved March 19, 2018, from http://www.ingersolltimes.com/2013/07/08/horse-milk-an-expensive-delicacy

Park1, I.M. 2009. Mongolia: Land of Milk and Horses. The Atlantik, Retrieved March 19, 2018, from https://www.theatlantic.com/health/archive/2009/10/mongolia-land-of-milk-andhorses/28949/

Stephano, R.M. 2018. Top 10 Medical Tourism Destinations in the World. Medical Tourism Magazine, February, Retrieved March 21, 2018, from http://www.medicaltourismmag.com/ top-10-medical-tourism-destinations-world/

Tegin, R.A.A., Gönülalan, Z. 2014. Bütün Yönleriyle Doğal Fermente Ürün Kımız. Manas Journal of Enginering 2(1), 21-34 (in Turkish).

Temizkan, S. P., Çiçek, D., Özdemir, C. 2015. Sağlık Turizmi Konusunda Yayınlanan Makalelerin Bibliyometrik Profili. International Journal of Human Sciences 12(2), 394-415 (in Turkish).

The Health Foundation of Turkey 2010. Dünyada ve Türkiye'de Sağllk Turizmi-2010 Durum Tespit Raporu ve Çözüm Önerileri. Efil Yayınevi, Ankara. Retrieved March 10, 2018, from https://docs.wixstatic.com/ugd/5bfofd_f9o860539e974cc9accd12531e4366oe.pdf (in Turkish)

Tourism Data of Kyrgyz Republic National Statistics Committee 2016. Retrieved March 19, 2018, from http://stat.kg/en/statistics/turizm/

Turkish Association of Health Tourism 2018. Sağllk Turizmi Genel Bilgi, Retrieved March 10, 2018, from http://www.saglikturizmi.org.tr/tr/saglik-turizmi/genel-bilgi (in Turkish)

Turkish Republic of Ministry of Culture and Tourism 2018a. Sağlık ve Termal Turizm Tanımı, Retrieved March 21, 2018, from http://yigm.kulturturizm.gov.tr/TR\%2C11492/saglik-ve-termal-turizmi-tanimi.html (in Turkish).

Turkish Republic of Ministry of Culture and Tourism 2018b. İzmir İl ve Kültür Turizm Müdürlüğ̈̈, Retrieved March 10, 2018, from http://www.izmirkulturturizm.gov.tr/ TR,77387/kemalpasa-alas-kazak-vadisi-kimiz-ciftligi.html (in Turkish).

Türsab Health Tourism Report 2013. Retrieved March 10, 2018, from https://onedrive.live.com/ view.aspx?cid=9bbfa $4347 \mathrm{~d} 80 \mathrm{ob} 625 \& \mathrm{id}=$ documents\& resid=9BBFA4347D80B625\%21431\&ap$\mathrm{p}=$ WordPdf\&authkey=ACdcb6)toOxWSho\& (in Turkish)

UNWTO Faits Saillants OMT du Tourisme Edition 2017. Retrieved March 21, 2018, from https://www.e-unwto.org/doi/pdf/10.18111/9789284419050 
UNWTO World Tourism Barometer 2018. Volume: 16, January, Retrieved March 21, 2018, from http://cf.cdn.unwto.org/sites/all/files/pdf/unwto_barom18_o1_january_excerpt_hr.pdf

Western Mediterranean Development Agency 2013. Sağlık Turizmi Sektör Raporu, Mayıs, Retrieved March 25, 2018, from http://www.baka.org.tr/uploads/48947588121518SAGLiK-KATALOG-TURKCE-16MAYiS-3.pdf (in Turkish).

Yaygın, H. 1993. Kımız ve Sağlıkla İlgili Özellikleri. The Journal of Food 16(2), 111-115.

Yılmaz, L., Kurdal, E. 2002. Eskimeyen Bir Süt İçkisi: Kımız. Gıda ve Yem Bilimi Teknolojisi Dergisi (1), 43-47. (in Turkish).

Yirik, Ş. 2014. Sağlık Turizmi Üzerine Antalya Destinasyonunda Bir Araştırma. Yayımlanmamış Doktora Tezi, Akdeniz Üniversitesi Sosyal Bilimler Enstitüsü, Turizm İşletmeciliği ve Otelcilik Ana Bilim Dalı, Antalya. (in Turkish).

Zengingönül, O., Emeç, H., İyilikçi, D.E., Bingöl, P. 2012. Sağllk Turizmi: İstanbul'a Yönelik Bir Değerlendirme. Ekonomistler Platformu İstanbul Kalkınma Ajansı, İstanbul. (in Turkish).

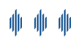

http://kimizciftligi.com/basinda-biz [Retrieved March 21, 2018] (in Turkish).

http://www.paardenmelk.be [Retrieved March 19, 2018].

http://www.paardenmelkerij.info/n/en/visits [Retrieved March 21, 2018].

http://www.worldometers.info/world-population/ [Retrieved March 21, 2018].

http://санаторий-юматово.рф/кумысолечение [Retrieved March 21, 2018] (in Russian).

https://en.wikipedia.org/wiki/Sanatorium [Retrieved March 10, 2018].

https://ru.sputnik.kg/infographics/20170525/1033394423/kumysolechenie-v-kyrgyzstane.html

[Retrieved March 19, 2018] (in Russian).

https://ru.wikipedia.org/wiki/Кyрорт [Retrieved March 10, 2018] (in Russian).

https://sankurtur.ru/methods/1986\#kumys-6 [Retrieved March 10, 2018] (in Russian).

https://www.managerprogramm.de/wp-content/uploads/2015/o7/MP-BWI-KAS-2015-036.jpg

[Retrieved March 10, 2018].

https://www.zakon.kz/4776853-kumys-kak-lekarstvo.html [Retrieved March 19, 2018] (in Russian). 